Article

\title{
Testing the Environmental Kuznets Curve Hypothesis for Biodiversity Risk in the US: A Spatial Econometric Approach
}

\author{
Justin Tevie *, Kristine M. Grimsrud and Robert P. Berrens \\ Department of Economics, University of New Mexico, Albuquerque, NM 87131, USA; E-Mails: \\ grimsrud@unm.edu (K.M.G.); rberrens@unm.edu (R.P.B.) \\ * Author to whom correspondence should be addressed; E-Mail: lga@unm.edu; \\ Tel.: +1-505-277-5304; Fax: +1-505-277-9445.
}

Received: 30 September 2011; in revised form: 7 November 2011 / Accepted: 8 November 2011 / Published: 16 November 2011

\begin{abstract}
This study investigates whether the environmental Kuznets curve (EKC) relationship is supported for a measure of biodiversity risk and economic development across the United States (US). Using state-level data for all 48 contiguous states, biodiversity risk is measured using a Modified Index (MODEX). This index is an adaptation of a comprehensive National Biodiversity Risk Assessment Index. The MODEX differs from other measures in that it is takes into account the impact of human activities and conservation measures. The econometric approach includes corrections for spatial autocorrelation effects, which are present in the data. Modeling estimation results do not support the EKC hypothesis for biodiversity risk in the US. This finding is robust over ordinary least squares, spatial error, and spatial lag models, where the latter is shown to be the preferred model. Results from the spatial lag regression show that a $1 \%$ increase in human population density is associated with about a $0.19 \%$ increase in biodiversity risk. Spatial dependence in this case study explains $30 \%$ of the variation, as risk in one state spills over into adjoining states. From a policy perspective, this latter result supports the need for coordinated efforts at state and federal levels to address the problem of biodiversity loss.
\end{abstract}

Keywords: biodiversity risk; environmental Kuznets curve; United States; spatial econometrics 


\section{Introduction}

As with numerous other countries and regions [1], there is increasing concern over the rapid loss of biodiversity in the United States (US) [2]. The importance of this "biodiversity crisis" (Mooney [3]) at both national and international levels is seen through connections to ecosystem services. Biodiversity crosses different organizational levels of genes, species, and ecosystems to support the functionality of ecosystems [4,5]. There is an increasing body of research linking the functionality of ecosystems to human welfare and the maintenance of sustainable social and economic systems that depend upon those ecosystems [3]. Diverse species interactions within the structural characteristics of ecosystems support the flow of services that provide benefits to human societies. Broad categories of service flows include: provisioning (e.g., food, fiber, and pharmaceuticals); regulating (flood control, disease control and water purification); and cultural (aesthetic, spiritual, and recreational) [1]. Social and economic systems interact and affect biodiversity through landscapes (e.g., from degraded habitats to protected wilderness areas, and watersheds for urban water supplies), myriad production and consumption choices [6,7], the laws we enact (e.g., the US Endangered Species Act [8], and the international Convention on Biodiversity [3]), and the values we hold (e.g., amenity, option and existence values for species protection) $[9,10]$.

Biologists and conservationists have expended significant effort to understand the factors that account for the decline in biodiversity, and communicate their importance in a policy context $[3,11]$. Understanding the empirical relationship between biodiversity risk and economic growth measures can help ground these efforts. The environmental Kuznets curve (EKC) hypothesis postulates an inverted U-shaped relationship between some environmental degradation measure (graphed on the vertical axis) and some measure of economic growth or welfare, such as the level of per capita income (graphed on the horizontal axis). In other words, under the EKC hypothesis environmental degradation is initially expected to rise with increases in economic development and then fall after per capita income passes beyond a certain critical threshold (or income "turning point"). Mixed empirical evidence in support of the EKC hypothesis has sometimes been construed to imply that countries (or states and regions) can simply grow their economy out of environmental degradation [12,13]. Yet, many authors are highly skeptical of this idea because of the mixed pattern of evidence supporting the EKC, that many estimated income turning points are at extremely high level, and broader notions of ecological thresholds and environmental carrying capacities [14].

The accumulated evidence from a number of meta-analyses [15-17] shows that the absence or presence of an EKC relationship systematically varies across the type of environmental degradation measure investigated, as well as a number of data and study methodology characteristics. Whether an EKC relationship holds for biodiversity risk, especially across states within any single large country like the US, remains an open empirical question. The mixed results from the meta-analyses suggest that some measures of environmental degradation are complex in nature and hard to measure, such as transboundary pollution and biodiversity risk. In addition, the presence of measurement issues coupled with the fact that biodiversity risk may be a complex environmental bad, may be the basis for not expecting an EKC relationship for biodiversity risk [17].

This study develops a state-level multivariate index for the US, titled here as the Modified Index (MODEX). The MODEX is modified from the national biodiversity risk assessment index (NABRAI), 
developed by Reyers et al. [18] and Reyers and James [19], to handle geographic units (e.g., states or regions) within a single country. The objective is to investigate the EKC hypothesis for a broad measure of biodiversity risk in the US. Using state-level data for this constructed biodiversity risk index, the econometric modeling also corrects for spatial issues, and controls for a variety of economic and political factors. Estimation results provide no evidence to support the EKC hypothesis for biodiversity risk in the US. The results, however, demonstrate the significance of spatial spillover effects in explaining biodiversity risk among US states.

\section{Background}

The concept of an EKC, within the field of environmental and resource economics, was initiated with the work of Grossman and Krueger [20] and Shafik and Banyopadhyay [21]. They adapted the hypothesis from Kuznets [22], who had postulated an inverted U-shape relationship between income inequality and economic development [23]. Grossman and Krueger [20] used panel data from 42 nations to find an EKC relationship for different measurements of air quality and economic development. In some of the earliest studies, Selden and Song [24] found evidence to support an EKC relationship for sulphur dioxide $\left(\mathrm{SO}_{2}\right)$, while Grossman and Krueger [25] found that water pollution declines monotonically with per capita income, while carbon emissions rise with per capita income.

Since these early studies, environmental and resource economists and others have conducted numerous empirical EKC studies across a wide range of environmental pollution or degradation measures. As select examples, Deacon and Norman [26], and Merlevede et al. [27], conducted EKC studies relating to air pollution. Paudel et al. [28] examined water pollution, Barbier [29] and Culas [30] examined deforestation, and Rupasingha et al. [31] examined hazardous waste and toxins. While less common than cross-national studies, a number of EKC studies have been conducted for spatial data (e.g., counties, states or regions) within a single country. For example, Wang et al. [32] examined hazardous waste sites in the US and found evidence to support an EKC relationship. With well over 100 empirical studies from 1992-2009 and with almost 900 estimated relationships, a series of meta-analyses have been published over the last decade [15-17], each building on the previous data set. The meta-analyses show that the absence or presence of an EKC relationship, and any expected income turning point (decoupling), depends significantly on the type and measure of environmental degradation or risk measure, scale and location, data characteristics and chosen estimation methods.

A number of theoretical reasons have been hypothesized to cause the EKC observed for select environmental degradation and pollution measures. These include: income elasticity of environmental quality demand [33]; scale, technological and composition effects in an economy [34]; the pollution haven hypothesis [35] for polluting industries or firms; and a migration hypothesis [36] where relatively higher income and mobile households move away from accumulating environmental degradation. However, accompanying this growth in the EKC literature have been sharp criticisms related to inconsistencies or ambiguities in the theoretical modeling, as well as concerns over econometric and statistical analyses.

The empirical question of an EKC relationship for biodiversity measures has largely been studied using simple indices of population stock values. The results are mixed. Dietz and Adger [37] examined the determinants of the number of species across a number of tropical countries and find no evidence of 
an EKC relationship between per capita income and biodiversity loss. McPherson and Nieswiadomy [38] investigate the EKC hypothesis for the percent of threatened species using cross-sectional data from 113 countries and find an N-shaped relationship between threatened birds and the level of per capita income (while controlling for spatial autocorrelation). They found no evidence, however, to support the EKC relationship for threatened mammals. Lantz and Martinez-Espineira [39] use panel data on bird populations in five different habitats from nine provinces in Canada and find evidence to support the EKC hypothesis for three of the five bird population habitat types.

A broader biodiversity risk index, like the one applied in this study, can be constructed by considering three key variables, namely, stock, pressure and response variables [40]. A stock variable typically refers to a state's biological richness or endemism. Pressure variables indicate a threat or danger to biodiversity. A response variable indicates a state's efforts towards conservation. The National Biodiversity Risk Assessment Index (NABRAI) [18,19] and its variants consider human pressure and response variables along with stock variables. Mozumder et al. [41] examined the EKC hypothesis for a cross-section of countries using three versions of the comprehensive NABRAI index. After controlling for variables such as trade, foreign direct investment, foreign aid and number of tourists in their econometric model, they found no evidence to support an EKC relationship for biodiversity risk. An unanswered empirical question is whether an EKC relationship for biodiversity risk exists within a single country, such as in the case of the US (where access to data for a more complex index is relatively good). If so, an EKC result could imply that at least some nations may be able to show internal evidence of reducing the problem of biodiversity loss within a given pattern of economic development.

The construction of a broad biodiversity risk for the US raises spatial data concerns. The data collected for the biodiversity risk measures are based on political boundaries, i.e., states, while the geographical distributions of species do not closely follow those political borders. Instead species' distributions are determined by ecological and geophysical factors that can transcend political boundaries. The presence of spatial dependency implies that biodiversity risk in one state can spill over into neighboring states. These arguments are seen in some related EKC studies, notably those by McPherson and Nieswiadomy [38] on threatened birds and mammal species in 113 countries, and species imperilment investigations by Pandit and Laband [42]. These econometric studies identify the need to address and test for potential spatial autocorrelation, as the factors that determine biodiversity risk are likely to extend beyond arbitrary political boundaries like state borders. In a similar context, Maddison [43] contends that pollution emissions behavior of countries could be related to behaviors that exist in neighboring countries. He investigated the EKC hypothesis for four pollutants (sulphur dioxide, nitrogen oxides, volatile organic compounds and carbon monoxide) in 135 countries using data for the years 1990 and 1995. Using four specifications of the spatial weights matrix, tests showed the presence of spatial autocorrelation. He specified a first-difference model to examine the EKC hypothesis for each pollutant, and did not find evidence to support the EKC relationship. However, the results showed that spatial spillover effects were present. Building from these previous studies, this study explicitly accounts for spillover effects using spatial econometric or statistical methods. 


\section{Data Sources}

Data for the 48 contiguous US states analyzed in this study were obtained from several sources. Table 1 summarizes the descriptive statistics for the variables used in the econometric modeling. The analysis uses 2007 as the reference year; in some case, data is for a proximal Census year or a year in close range.

Table 1. Variable Definitions and Descriptive Statistics.

\begin{tabular}{|c|c|c|c|c|c|}
\hline Variable & Description & Mean & Min. & Max. & Std. \\
\hline LNMODEX & $\log$ of MODEX, MODEX = 2PR/(RE + ST $)$ & -0.968 & -1.885 & 0.000 & 0.348 \\
\hline LNPOPDENSE & $\begin{array}{l}\text { Natural logarithm of population density (number } \\
\text { of persons per square mile) in a state in } 2007\end{array}$ & 4.494 & 1.676 & 6.899 & 1.205 \\
\hline PFOREST & $\begin{array}{l}\text { Percentage of industrial activity in a state } \\
\text { accounted for by forestry in } 2007\end{array}$ & 0.002 & 0.0002 & 0.010 & 0.002 \\
\hline PMINE & $\begin{array}{l}\text { Percentage of industrial activity in a state } \\
\text { accounted for by mining in } 2007\end{array}$ & 0.026 & 0.0002 & 0.300 & 0.054 \\
\hline PCONST & $\begin{array}{l}\text { Percentage of industrial activity in a state } \\
\text { accounted for by construction in } 2007\end{array}$ & 0.046 & 0.029 & 0.086 & 0.010 \\
\hline LNSQMILES & $\begin{array}{l}\text { The natural logarithm of the land area in a state } \\
\text { measured in square miles }\end{array}$ & 10.684 & 7.342 & 12.500 & 1.058 \\
\hline PERCAP & Mean state per capita income 2007 dollars & 36,324 & 24,147 & 58,071 & 6,598 \\
\hline COASTAL & $\begin{array}{l}\text { Dummy variable equal to } 1 \text { if a state has a coast } \\
\text { and } 0 \text { otherwise }\end{array}$ & 0.437 & 0 & 1 & 0.501 \\
\hline SENATE & $\begin{array}{l}\text { The number of times a state Senator voted in } \\
\text { favor of key environmental protection issues in } \\
\text { the US Congress in } 2007\end{array}$ & 53.395 & 0 & 93 & 31.977 \\
\hline HOUSE & $\begin{array}{l}\text { The number of times a state Representative } \\
\text { voted in favor of key environmental protection } \\
\text { issues in the US House of Representatives } \\
\text { in } 2007\end{array}$ & 54.895 & 0 & 100 & 26.153 \\
\hline
\end{tabular}

Information on threatened and endangered species was collected from the US Department of Interior's, Fish and Wildlife Service [44]. Data on the major uses of land in the US were obtained from the US Department of Agriculture's, Economic Research Service [45]. Urban growth information was obtained from Nowak and Walton [46]. The human population and per capita income data were obtained from the US Department of Commerce's, Census Bureau [47]. The percentage of industrial activity accounted for by mining, forestry and construction were constructed with data from the US Department of Commerce's, Bureau of Economic Research [48]. The League of Conservation Voters [49] provided data on votes cast on major environmental issues by Senators and Representatives in the US Congress. Data on species density, endemic species, and the number of species were collated from Stein [50]. The amount allocated to each state under the Pittman-Robertson Wildlife Restoration Act by the US Department of Interior [51], for 2007, was used as a proxy for the total conservation budget.

Data on genetic resources and reference collections were obtained from the Museum of Southwestern Biology (University of New Mexico) multi-collection database [52]. This includes the total number of plant, animal and microbial genetic resource collections and the total number of reference collections 
found in museums. State-level data used to construct the MODEX were collected from a variety of sources. A detailed description of each of the variables used in constructing the MODEX is provided in Table 2.

Table 2. Variables, Definitions, Sources and Explanation of the Variables Used in Constructing the MODEX.

\begin{tabular}{|c|c|c|c|}
\hline Variable & Definition & Source & \begin{tabular}{|c|} 
Explanation \\
\end{tabular} \\
\hline th & $\begin{array}{l}\% \text { threatened and } \\
\text { endangered } \\
\text { species }\end{array}$ & $\begin{array}{l}\text { US Dept. of the Interior/Fish } \\
\text { and Wildlife Service [44] }\end{array}$ & $\begin{array}{l}\text { The percentage of total mammal, bird, } \\
\text { reptile, amphibian and higher plant species } \\
\text { that are endangered or threatened. }\end{array}$ \\
\hline$p d$ & $\begin{array}{l}\text { human } \\
\text { population index }\end{array}$ & US Census Bureau [47] & $\begin{array}{l}\text { Human population density (number of } \\
\text { people per square mile). }\end{array}$ \\
\hline hd & $\begin{array}{l}\text { High disturbance } \\
\text { intensity }\end{array}$ & $\begin{array}{l}\text { US Dept. of Agriculture's, } \\
\text { Economic Research } \\
\text { Service [45], Nowak and } \\
\text { Walton [46] }\end{array}$ & $\begin{array}{l}\text { The percentage of total land acreage used } \\
\text { for cropland, grassland pasture and range, } \\
\text { urban areas, urban growth and logged areas. }\end{array}$ \\
\hline$c b$ & $\begin{array}{l}\text { Natl. } \\
\text { conservation } \\
\text { budget }\end{array}$ & $\begin{array}{l}\text { US Dept. of the Interior/Fish } \\
\text { and Wildlife Service [44] }\end{array}$ & $\begin{array}{l}\text { The amount allocated to each state under } \\
\text { the Pittman-Robertson Wildlife Restoration } \\
\text { Act for fiscal year } 2007 \text { divided by the } \\
\text { gross domestic product per capita. }\end{array}$ \\
\hline$p l$ & Protected land & $\begin{array}{l}\text { US Department of } \\
\text { Agriculture/Economic } \\
\text { Research Service [45] }\end{array}$ & $\begin{array}{l}\text { The percentage of land that include areas in } \\
\text { national and state park systems and national } \\
\text { wilderness and primitive areas plus about } \\
2.5 \text { million acres in New York classified as } \\
\text { State forest preserves. Estimates exclude } \\
\text { large water bodies and parks in urban areas. }\end{array}$ \\
\hline$g r$ & $\begin{array}{l}\text { Genetic resource } \\
\text { allocations }\end{array}$ & $\begin{array}{l}\text { Museum of Southwestern } \\
\text { Biology at the University of } \\
\text { New Mexico [52] }\end{array}$ & $\begin{array}{l}\text { The total number of plant, animal and } \\
\text { microbial genetic resource collections. }\end{array}$ \\
\hline re & $\begin{array}{l}\text { Reference } \\
\text { collections }\end{array}$ & $\begin{array}{l}\text { Museum of Southwestern } \\
\text { Biology at the University of } \\
\text { New Mexico [52] }\end{array}$ & $\begin{array}{l}\text { The total number of reference collections } \\
\text { found in museums. }\end{array}$ \\
\hline$s d$ & Species density & Stein $[50]$ & $\begin{array}{l}\text { Calculated as the number of species per } \\
1000 \text { hectares of land. Species include } \\
6 \text { taxa groups - plants, animals, birds, } \\
\text { reptiles, amphibians and fishes. }\end{array}$ \\
\hline en & $\begin{array}{l}\% \text { endemic } \\
\text { species }\end{array}$ & Stein $[50]$ & $\begin{array}{l}\text { Species that is unique or restricted to a } \\
\text { particular state. }\end{array}$ \\
\hline$l d$ & $\begin{array}{l}\text { Low disturbance } \\
\text { intensity }\end{array}$ & $\begin{array}{l}\text { US Dept. of Agriculture, } \\
\text { Economic Research } \\
\text { Service [45] }\end{array}$ & $\begin{array}{l}\text { The percentage of total land that include } \\
\text { uses not inventoried as well as marshes, } \\
\text { open swamps, bare rock areas, desert, } \\
\text { tundra, and other land generally of low } \\
\text { value for agricultural purposes. }\end{array}$ \\
\hline
\end{tabular}




\section{Methods}

The construction of the MODEX, the biodiversity risk index used in this study, follows Reyers et al. [18] and Reyers and James [19] who formulated a broad multivariate biodiversity risk index, the NABRAI. They use the NABRAI to rank 28 countries in 1999 and 103 countries in 1998 in terms of their biodiversity risk on a scale from zero to one, where zero is the lowest risk and one is the highest risk. In the construction of the NABRAI, these studies first classify variables into three categories: stock (ST), pressure (PR) and response variables (RE). PR variables include percentage of land area exposed to high disturbance level, percentage threatened species and population density. RE variables include conservation budget, percentage land area protected, number of genetic resource allocations, reference collections and conventions. The ST variable includes the percentage of land area exposed to low density, endemic species and species density. By adding up the values of the various components of PR, ST and RE, Reyers et al. [18] construct the initial version of the NABRAI using the formula:

$$
N A B R A I=P R /(R E+S T)
$$

Reyers and James [19] later construct the upgraded and improved index, denoted by NABRAI* as follows:

$$
N A B R A I^{*}=2 P R /(R E+S T)
$$

where PR, RE and ST are the total pressure value, total response value and total stock value, respectively. The numerator in the upgraded formula is multiplied by two in order to afford it the same weight as the denominator.

In constructing the NABRAI*, all component variables are ranked from one to the highest value and these ranks are then used to calculate the pressure, response and stock values as follows:

$$
\begin{gathered}
P R=(t h+p d+h d) / 3 \\
R E=(c b+p l+g r+r e+c o) / 5 \\
S T=\sqrt{l d(s d+e n) / 2}
\end{gathered}
$$

where: $t h=$ percentage threatened species rank, $p d=$ human population index, $h d=$ high disturbance intensity rank, $c b=$ national conservation budget rank, $p l=$ protected land rank, $g r=$ genetic resource allocations rank, $r e=$ reference collections rank, $c o=$ biodiversity convention rank, $s d=$ species density rank, en = percentage endemic species rank, and $l d=$ low disturbance intensity rank. In order to afford comparisons on a unit interval, NABRAI* is normalized to lie between 0 and 1 .

The MODEX has a similar construction as NABRAI* except that it is modified to compare biodiversity risk of political units within a country. NABRAI*, the upgraded index, was chosen over NABRAI because the former is unitless [19]. Compared to the NABRAI* the biodiversity convention rank was omitted in the MODEX because the rank applies to sovereign countries and not to states within a country. Like the NABRAI*, the MODEX is normalized to lie between 0 (low biodiversity risk) and 1 (high biodiversity risk) allowing comparisons on the unit interval. A low value of biodiversity risk (MODEX), implies that a particular US state has a combination of low pressure values and high response and stock values. On the other hand, a high biodiversity risk (MODEX) 
implies that a particular state has a combination of high pressure values and low response and stock values by virtue of the way the index is constructed.

Table 3 below shows the calculated MODEX value and per capita income for the various states. In general, spatial patterns are suggested by Table 3. States with similar per capita income and MODEX values seem to be clustered together. In other words, states that are closer to each other generally exhibit more similar values than those far apart. As select examples, western states such as California, Oregon and Washington have MODEX and per capita income values that are similar. In the eastern US, Florida, Georgia and North Carolina also exhibit similar MODEX and per capita income values.

Table 3. Comparison of MODEX and 2007 Per Capita Income for US States.

\begin{tabular}{lcc|lcc}
\hline State & MODEX & Income Per Capita & State & MODEX & Income Per Capita \\
\hline Alabama & 0.494 & 29,426 & Nebraska & 0.482 & 37,991 \\
Arizona & 0.317 & 33,300 & Nevada & 0.305 & 40,657 \\
Arkansas & 0.421 & 27,810 & New Hampshire & 0.254 & 37,829 \\
California & 0.412 & 42,319 & New Jersey & 0.481 & 44,834 \\
Colorado & 0.332 & 40,742 & New Mexico & 0.466 & 30,624 \\
Connecticut & 0.509 & 51,139 & New York & 0.341 & 48,869 \\
Delaware & 0.572 & 58,071 & North Carolina & 0.352 & 36,398 \\
Florida & 0.423 & 33,702 & North Dakota & 0.357 & 35,454 \\
Georgia & 0.341 & 34,792 & Ohio & 0.486 & 33,829 \\
Idaho & 0.234 & 30,442 & Oklahoma & 0.264 & 28,851 \\
Illinois & 1.000 & 40,142 & Oregon & 0.395 & 38,751 \\
Indiana & 0.469 & 33,317 & Pennsylvania & 0.307 & 35,337 \\
Iowa & 0.493 & 36,243 & Rhode Island & 0.575 & 36,516 \\
Kansas & 0.603 & 34,571 & South Carolina & 0.295 & 28,676 \\
Kentucky & 0.698 & 29,986 & South Dakota & 0.394 & 36,791 \\
Louisiana & 0.253 & 33,022 & Tennessee & 0.492 & 34,012 \\
Maine & 0.152 & 30,248 & Texas & 0.499 & 38,055 \\
Maryland & 0.564 & 38,788 & Utah & 0.281 & 32,413 \\
Massachusetts & 0.441 & 47,388 & Vermont & 0.247 & 34,383 \\
Michigan & 0.253 & 32,940 & Virginia & 0.415 & 41,608 \\
Minnesota & 0.295 & 41,060 & Washington & 0.401 & 40,218 \\
Mississippi & 0.419 & 24,147 & West Virginia & 0.306 & 24,970 \\
Missouri & 0.403 & 32,532 & Wisconsin & 0.265 & 35,178 \\
Montana & 0.190 & 27,991 & Wyoming & 0.219 & 39,807 \\
\hline
\end{tabular}

Certainly, there may be other approaches to constructing a composite biodiversity index. Although not pursued here, alternatives to constructing other composite indices (although not specific to biodiversity), are seen in two recent EKC papers (Jha and Murthy [53]; and Paudel and Schafer [54]). Jha and Murthy [53] employed a principal components method to create an environmental degradation index (EDI) using six environmental degradation indicators: biodiversity destruction, deforestation, fresh water depletion, build up of toxic and non-toxic wastes, paper consumption, and natural resource erosion to study the EKC relationship for a cross-section of countries. Paudel and Schafer [54] developed a social capital index (SCI) using principal components analysis with variables such as number of business associations, professional organizations, public golf courses and bowling centers. 
The SCI is then used as an explanatory variable to study the EKC relationship for Louisiana using parish-level data. The focus here is on using the MODEX in an EKC investigation of biodiversity in the US; this index is a modification of the NABRAI, which has been developed and discussed in the ecology and biodiversity conservation literature.

Using the MODEX constructed with US data for the year 2007 (or the nearest available year between 2002 and 2011), the following econometric analysis of an EKC relationship for biodiversity risk is limited to a cross-sectional snapshot. Still this measure of biodiversity risk, like the NABRAI index, is more dynamic (if tracked over significant periods) than alternative measures. Biodiversity risk can increase or decrease over time because pressure and response activities fluctuate over time thus making it vary over time. On the other hand, pure biodiversity measures involving the number of species or percentage change of any particular species category (plant, birds and mammals) are typically static or declining over time. These dynamic effects cannot be estimated because the different data sources required did not permit for a time varying MODEX.

\section{Modeling Considerations}

The specification of the econometric model is based on prior EKC studies that use some measure of environmental degradation as the dependent variable, and per capita income, its squared and cubic terms are included as independent variables. Additional covariates, $\mathbf{Z}$, are also included (or controlled for) in many EKC studies. The following econometric model is specified to investigate the EKC hypothesis for biodiversity risk:

$$
\operatorname{LNMODEX}_{i}=\beta_{0}+\beta_{1} \operatorname{PERCAP}_{i}+\beta_{2} \operatorname{PERCAP}_{i}^{2}+\beta_{3} \operatorname{PERCAP}_{i}^{3}+\mathbf{Z}^{\prime} \gamma+\varepsilon_{i}
$$

where $i$ indexes states, LNMODEX $_{i}$ is the natural logarithm of $\operatorname{MODEX}_{i}, \operatorname{PERCAP}_{i}$ is the per capita income (measured in thousands of dollars), and $\varepsilon_{i}$ is the stochastic error term assumed to be normally distributed. Equation (6) enables tests for various relationships between LNMODEX and per capita income variables as follows:

(i) $\beta_{1}=0, \beta_{2}=0$, and $\beta_{3}=0$ implies a flat pattern or no relationship.

(ii) $\beta_{1}>0, \beta_{2}=0$, and $\beta_{3}=0$ implies a monotonically increasing relationship or a linear relationship.

(iii) $\beta_{1}<0, \beta_{2}=0$, and $\beta_{3}=0$ implies a monotonically decreasing relationship

(iv) $\beta_{1}>0, \beta_{2}<0$ and $\beta_{3}=0$ implies an inverted U-shaped relationship, i.e., the EKC hypothesis.

(v) $\beta_{1}<0, \beta_{2}>0$ and $\beta_{3}=0$ implies a U-shaped relationship.

(vi) $\beta_{1}>0, \beta_{2}<0$ and $\beta_{3}>0$ implies a cubic polynomial or $\mathrm{N}$-shaped figure.

(vii) $\beta_{1}<0, \beta_{2}>0$ and $\beta_{3}<0$ implies a relationship opposite to the $\mathrm{N}$-shaped curve.

The choice of covariates, $\mathbf{Z}$, in Equation (6) is driven by a mix of theory and empirical findings of numerous EKC studies. Land conversion and deforestation have negative effects on plant and animal species [55]. Road construction and other infrastructure development contribute to species imperilment [56]. The variables PCONST (percent of industrial activity accounted for by construction), PMINE (percent of industrial activity accounted for by mining activities), and PFOREST (percent of industrial activity accounted for by forestry) are included to control for human activities such as deforestation, mining, and construction activities that encroach on the habitats of many plant and animal species. 
The variable LNPOPDENSE (the natural log of population density) is included to control for population density in each state. Kerr and Currie [57] show that population density (as measured by persons per square mile) in a geographical region is positively related to the percent of threatened and/or endangered plant and animal species. The variable LNSQMILES (the natural log of the square mile of each state) partially controls for how land mass is related to the number of plant and animal species. Pandit and Laband [58] asserted that in many cases it is reasonable to believe that land area and the number of plant and animal species are negatively related: larger land areas may span a greater number of different ecosystems.

The spatial weights matrix takes into account only the length of a border shared by neighboring states, but does not include the length or in anyway account for the coastal border (ocean/sea). Coastal regions are also more prone to additional pressure activities such as fishing and off-shore oil drilling. The dummy variable COASTAL, which equals one if the state has a coast zero otherwise, is included to capture these effects. This is viewed as a separate effect from the more general possibility of unobserved spatial spillovers between states. The socio-political regime may influence the income-environment relationship via the type of environment policies formulated and implemented by policymakers [59]. Two variables are included to control for socio-political regime. The variables SENATE and HOUSE represent votes in favor of key environmental protection issues of Senators and Representatives, by state, in the US Senate and the House of Representatives, respectively. Based on this discussion, the term $\mathbf{Z}^{\prime} \gamma$ in Equation (6) is defined as:

$$
\begin{aligned}
\mathbf{Z}^{\prime} \gamma & =\gamma_{4} \mathrm{PCONST}_{i}+\gamma_{5} \mathrm{PMINE}_{i}+\gamma_{6} \mathrm{PFOREST}_{i}+\gamma_{7} \mathrm{LNSQMILES}_{i} \\
& +\gamma_{8} \mathrm{LNPOPDENSE}_{i}+\gamma_{9} \mathrm{COASTAL}_{i}+\gamma_{10} \mathrm{SENATE}_{i}+\gamma_{11} \mathrm{HOUSE}_{i}
\end{aligned}
$$

In conformity with the above discussion, it can be hypothesized that $\gamma_{4}>0, \gamma_{5}>0, \gamma_{6}>0, \gamma_{7}<0$, $\gamma_{8}>0, \gamma_{9}<0, \gamma_{10}<0$, and $\gamma_{11}>0$.

\subsection{Spatial Autocorrelation}

In this study, spatial autocorrelation may be caused by the fact that political boundaries and the geographical distribution of species don't coincide. Spatial autocorrelation exists if the residuals from different geographical units are spatially correlated because they contain common omitted environmental or physical and economic factors [60]. The most common method used to correct for spatial autocorrelation is the spatial error model (spatial autoregressive process in the error term), which is formulated as ([61], pp. 34-35):

$$
\begin{gathered}
\mathrm{y}=\mathrm{X} \beta+\varepsilon \\
\varepsilon=\lambda \mathrm{W}+\mathrm{u} \rightarrow \varepsilon=(\mathrm{I}-\lambda \mathrm{W})^{-1} \mathrm{u}
\end{gathered}
$$

where $\mathrm{W}$ is a spatial weights matrix, $\lambda$ is the autoregressive coefficient, $\mathrm{X}$ is an $N \times K$ matrix of exogenous variables associated with the $K \times 1$ parameter vector, $\beta$, and $\mathrm{u}$ is an error term assumed to be homoscedastic and serially uncorrelated. Another common spatial regression model is the spatial lag model (spatial autoregressive dependent variable), which can account for the direct spatial effects of neighboring states. In this case, the classical linear model is specified as follows:

$$
\mathrm{y}=\rho \mathrm{Wy}+\mathrm{X} \beta+\varepsilon=(\mathrm{I}-\rho \mathrm{W})^{-1} \mathrm{X} \beta+(\mathrm{I}-\rho \mathrm{W})^{-1} \varepsilon
$$


where $\rho$ is the coefficient of the spatially lagged dependent variable. Both the spatial error model and the spatial lag model will be explored here. Spatial autocorrelation models require the specification of a spatial weights matrix among several options. The simplest spatial weights matrix is to assign values to each element in the matrix such that $w_{\mathrm{ij}}=1$ if states $i$ and $j$ share a common border and $w_{\mathrm{ij}}=0$ otherwise [62]. With $N=48$ states in the data set the spatial weights matrix is $48 \times 48$ consisting of 2,304 elements of zeroes or ones. The spatial weights matrix used here has cells that contain the length of a given state's border that is shared by another state. This can be considered the Rook criterion (locations sharing a boundary) and is commonly used in the literature to capture spatial effects.

\subsection{Endogeneity}

Endogeneity is a serious concern, especially in the context of MODEX. Several variables including population density and per capita income appear on both sides of Equation (6), as both explanatory variables themselves and as components in the construction of the composite index (MODEX). In addition, it is conjectured that the variables representing the percentage of industrial output devoted to mining, forestry and construction could be endogenous as well. This is potentially a problem due to the possibility of a simultaneity bias caused by endogeneity between the constructed MODEX index and per capita income, construction, mining and forestry variables. Per capita income generally depends on gross domestic product (GDP), which in turn can be positively related to increased industrial production (including mining, forestry, construction and other activities). In other words, per capita income, construction, mining and forestry may be jointly determined. In the case of simultaneity bias, OLS estimates are biased and inconsistent. However, endogeneity is an empirical question. To answer that question, a simple regression test of endogeneity, which is asymptotically equivalent to the Hausman test, is employed ([63], p. 287). This test involves two steps: (1) compute the residuals from a regression of endogenous variables on instruments (i.e., other predictor variables except per capita income, construction, mining and forestry); and (2) use these residuals in an OLS regression and test the joint hypothesis that the coefficients on the residuals are zero.

\section{Results}

Statistical analyses were undertaken using the software package Stata. First, the test results for endogeneity $(F=2.68)$ showed that the null hypothesis cannot be rejected at the $5 \%$ level; this indicates that per capita income, forestry, mining and construction variables are exogenous. Second, Geary's $c$ [64] and Moran's I [65], two diagnostic tests, were undertaken to verify the presence or absence of spatial autocorrelation in the variable LNMODEX. The results of these tests are presented in Table 4.

Table 4. Spatial Autocorrelation Tests for LNMODEX.

\begin{tabular}{llllrl}
\hline Test & Statistic & Mean & St. Dev. & Z-value & p-value \\
\hline Moran's $I$ & $I=0.168$ & -0.021 & 0.110 & 1.729 & 0.042 \\
Geary's $c$ & $c=0.719$ & 1.000 & 0.149 & -1.880 & 0.030 \\
\hline
\end{tabular}


As shown in Table 4, the $z$-value for Moran's $I$ test is positive and significant, which indicates the presence of positive spatial autocorrelation in LNMODEX. The $z$-value for Geary's $c$ test is negative and also significant, which also indicates the presence of positive autocorrelation. So states with similar MODEX values are generally adjacent to each other. As a result, the basic OLS model was also re-estimated correcting for spatial autocorrelation.

Table 5 presents the results of three models: Model 1-OLS regression; Model 2-spatial error regression; and Model 3 - spatial lag regression. The spatial econometric models (2 and 3) are estimated because tests indicate that spatial autocorrelation is present. Results indicate that the spatial lag effect (Model 3) is significant at the 1\% level, but the spatial error effect (Model 2) is not significant. Model 3 is also shown to have the highest adjusted $\mathrm{R}^{2}$. On the basis of these results, Model 3 is the preferred model. As shown in Table 5, none of the covariates are statistically significant in Model 1. In Models 2 and 3 , the estimated coefficients for the covariates PCONST and LNPOPDENSE are significant at the $10 \%$ and $5 \%$ levels, respectively. The variable LNPOPDENSE has the expected positive sign. The variable PCONST, surprisingly, has a negative sign. It is speculated that this may be due to the relative (construction measured as a percentage of total industrial activity) nature of this measure, rather than an absolute measure of construction activity.

Table 5. Estimation Results for all Three Models.

\begin{tabular}{|c|c|c|c|}
\hline Variable & Model 1 OLS & $\begin{array}{c}\text { Model 2 } \\
\text { Spatial Error Model }\end{array}$ & $\begin{array}{c}\text { Model 3 } \\
\text { Spatial Lag Model }\end{array}$ \\
\hline CONSTANT & $\begin{array}{l}-0.4768 \\
(-0.09)\end{array}$ & $\begin{array}{c}-5.6621 \\
(-1.67) *\end{array}$ & $\begin{array}{r}-4.4069 \\
(-1.02)\end{array}$ \\
\hline PERCAP & $\begin{array}{l}-0.0137 \\
(-0.04)\end{array}$ & $\begin{array}{l}0.362 \\
(1.47)\end{array}$ & $\begin{array}{c}0.2816 \\
(0.88)\end{array}$ \\
\hline PERCAP $^{2}$ & $\begin{array}{c}0.0011 \\
(0.12)\end{array}$ & $\begin{array}{l}-0.0087 \\
(-1.38)\end{array}$ & $\begin{array}{c}-0.0066 \\
(-0.81)\end{array}$ \\
\hline PERCAP $^{3}$ & $\begin{array}{c}-0.00001 \\
(-0.17)\end{array}$ & $\begin{array}{c}0.00007 \\
(1.34)\end{array}$ & $\begin{array}{c}0.00005 \\
(0.78)\end{array}$ \\
\hline PCONST & $\begin{array}{l}-6.5654 \\
(-1.14)\end{array}$ & $\begin{array}{l}-7.3738 \\
(-1.70) *\end{array}$ & $\begin{array}{l}-8.3550 \\
(-1.79) *\end{array}$ \\
\hline PFOREST & $\begin{array}{c}4.1445 \\
(0.11)\end{array}$ & $\begin{array}{c}27.7855 \\
(0.96)\end{array}$ & $\begin{array}{l}32.4470 \\
(1.00)\end{array}$ \\
\hline PMINE & $\begin{array}{l}-1.6462 \\
(-1.28)\end{array}$ & $\begin{array}{l}-1.0406 \\
(-1.06)\end{array}$ & $\begin{array}{l}-1.335 \\
(-1.28)\end{array}$ \\
\hline LNPOPDENSE & $\begin{array}{l}0.084 \\
(0.98)\end{array}$ & $\begin{array}{c}0.1680 \\
(2.56) * *\end{array}$ & $\begin{array}{l}0.01876 \\
(2.38) * *\end{array}$ \\
\hline LNSQMILES & $\begin{array}{l}-0.0530 \\
(-0.61)\end{array}$ & $\begin{array}{l}-0.1031 \\
(-1.58)\end{array}$ & $\begin{array}{l}-0.0998 \\
(-1.39)\end{array}$ \\
\hline SENATE & $\begin{array}{l}-0.0021 \\
(-0.88)\end{array}$ & $\begin{array}{l}-0.0096 \\
(-0.521)\end{array}$ & $\begin{array}{c}-0.0013 \\
(-0.71)\end{array}$ \\
\hline HOUSE & $\begin{array}{l}-0.0034 \\
(-0.46)\end{array}$ & $\begin{array}{l}0.0013 \\
(-0.42)\end{array}$ & $\begin{array}{c}-0.0032 \\
(-1.01)\end{array}$ \\
\hline COASTAL & $\begin{array}{l}-0.0802 \\
(-0.46)\end{array}$ & $\begin{array}{l}-0.0934 \\
(-0.71)\end{array}$ & $\begin{array}{l}-0.1701 \\
(-1.170)\end{array}$ \\
\hline
\end{tabular}


Table 5. Cont.

\begin{tabular}{cccc}
\hline Variable & Model 1 OLS & $\begin{array}{c}\text { Model 2 } \\
\text { Spatial Error Model }\end{array}$ & $\begin{array}{c}\text { Model } \\
\text { Spatial Lag Model }\end{array}$ \\
\hline$\lambda$ & 0.0001 & \\
$\rho$ & & $(1.54)$ & 0.0004 \\
$\mathrm{~N}$ & 48 & & $(2.73) * * *$ \\
Adj. $\mathrm{R}^{2}$ & 0.1 & 48 & 48 \\
\hline
\end{tabular}

Notes: * Indicates significance at the $10 \%$ level; ** indicates significance at the $5 \%$ level; and $* * *$ indicates significance at the $1 \%$ level. Numbers in parenthesis are the corresponding z-statistics for the spatial lag and error models, and the t-statistic for the OLS model.

Focusing on the preferred model, Model 3, the estimated spatial lag coefficient ( $\rho$ ) is statistically significant at the $1 \%$ level, which indicates that a $1 \%$ increase in biodiversity risk in a neighboring state leads to a $0.04 \%$ increase in risk in the home state. Furthermore, $30 \%$ of the variation in biodiversity risk is accounted for by spatial dependence [Adjusted $\mathrm{R}^{2}=0.40$ in the spatial lag model (Model 3) and 0.10 in the OLS model (Model 1)].

With respect to the EKC hypothesis, estimated coefficients on the linear, squared and cubic per capita income terms are not statistically significant from zero in Model 3 (or in any of the other models). Thus, the null hypotheses of $\beta_{1}=0, \beta_{2}=0$, and $\beta_{3}=0$ cannot be rejected which implies that there is no directional relationship, or turning points, between biodiversity risk and per capita income. Thus, using state-level US data, there is no empirical evidence that continued growth in the per capita income of US states ultimately will results in reduced biodiversity risk. Rather there is evidence of a decoupling of biodiversity risk and per capita income - a lack of an EKC relationship for biodiversity risk.

A number of other statistical issues that were addressed in this study are heteroscedasticity, multicollinearity and outliers. It is a challenge to correct for both heteroscedasticity and spatial autocorrelation concurrently. From an econometric standpoint, the presence of heteroscedasticity and/or spatial autocorrelation does not bias the OLS coefficient estimates, but the estimates will be inefficient. The troubling aspect, however, is that the standard errors will be biased leading to inaccurate statistical inference. The Breusch-Pagan [66] test was performed in order to test for the presence of heteroscedasticity.

The results of the Breusch-Pagan test revealed that the null hypothesis of homoscedasticity cannot be rejected at the $5 \%$ level $(\mathrm{P}$-value $=0.60)$. Further diagnostic tests performed on the model results presented indicate that multicollinearity and outliers are absent.

Finally, though not presented here, as a robustness check a specification with only per capita income variables as explanatory variables was also estimated for all three models. Consistent with our primary conclusions on the EKC hypothesis, the estimated coefficients on the linear, squared and cubic per capita income terms were not statistically significant. 


\section{Discussion}

This study investigated whether there is empirical evidence for the EKC hypothesis for biodiversity risk in the US. Using state-level data for the 48 contiguous states, OLS, spatial error and spatial lag models were estimated. Spatial econometric models were used because tests indicate that spatial dependence is present in the data on biodiversity risk. This is consistent with the notion that biodiversity risk is unlikely to adhere closely to simple political boundaries, such as state lines. The evidence showed that population density contributed significantly to biodiversity risk. This is consistent with expectations, and it is certainly not surprising that states with higher population densities are at more risk of biodiversity loss. Also the spatial lag effect is highly significant, but the spatial error effect is not significant. Furthermore, in the former model, most of the variation in biodiversity risk is accounted for by the spatial component. On the basis of these findings, the spatial lag model is the preferred model. Thus, the evidence is also consistent with the expectation from previous studies $[38,42]$ that biodiversity risk in one political unit spills over into adjacent units (states in this case study). From a policy standpoint, this result supports the arguments for coordinated efforts at the state and federal levels to arrest the decline in biodiversity.

The econometric evidence showed no support for the EKC hypothesis for biodiversity risk in the US, (i.e., per capita income variables are not statistically significant determinants of biodiversity risk). This result is robust across all three model specifications and is consistent with those of Mozumder et al. [41]. In their multi-country study, using several versions of the NABRAI [18,19], Mozumder et al. [41] also find that per capita income variables were not statistically significant, and there was no evidence for an EKC relationship for biodiversity risk across nations. The focus here has been on a national-level EKC investigation using a modification (MODEX) of the NABRAI, which was developed in the ecology and biodiversity conservation literature; valid future research investigations into the biodiversity-economic growth relationship might explore both alternative applications (e.g., other nations or regions), as well as alternative index construction [53,54] for a composite biodiversity measure.

In closing, as studies accumulate, it is perhaps natural to question the relevance of each additional empirical EKC study. Yet, over the last several decades a number of sources have argued or implied [12,13] that society will simply be able to grow itself out of significant environmental problems, and cite select EKC evidence to support the more general argument. Indeed, there is certainly some empirical evidence of EKC relationships, found in the literature and available meta-analyses [15-17] for some environmental degradation measures (e.g., local air and water pollutants). However, the results for more complex degradation measures such as biodiversity risk and transboundary pollutants $\left(\right.$ like $\left.\mathrm{CO}_{2}\right)$ appear to show no systematic evidence to support the EKC hypothesis [16,17]. That is, the EKC relationship should not serve as any kind of referent or assumed case. As such, the relevance of the current results are that attempts to reduce biodiversity risk in the US and elsewhere [41] would appear to require specific policy actions, rather than relying on any assumption or expectation of simply growing out of the problem. Further, due to anticipated spatial effects, it may be expected that successful policy actions will have to be coordinated across adjoining political units.

The more general policy lesson, which extends beyond this US case study (where available data is relatively rich), is that biodiversity risk is unlikely to adhere to simple political boundaries, and the 
consequent need to account for spatial effects in risk reduction efforts and analyses. This includes both national and international contexts. For example, as Mooney ([3], p. 32) recently argued in an international context, the focus on national sovereignty and jurisdiction in the international Convention on Biodiversity (crafted at the United Nations Rio Convention in 1992), without full consideration of the spatial effects of activities across "other states or areas beyond the limits of national jurisdictions," has severely limited its effectiveness as an international convention.

\section{Acknowledgements}

Research support was provided by the Department of Economics, and the Robert Wood Johnson Foundation Center for Health Policy at the University of New Mexico, Albuquerque NM.

\section{Conflict of Interest}

The authors declare no conflict of interest.

\section{References and Notes}

1. Millennium Ecosystem Assessment. Ecosystems and Human Well Being: Biodiversity Synthesis; World Resources Institute: Washington, DC, USA, 2005.

2. Lodge, D.M.; Williams, S.; MacIsaac, H.J.; Hayes, K.R.; Leung, B.; Reichard, S.; Mack, R.N.; Moyle, P.B.; Smith, M.; Andow, D.A.; Carlton, J.T.; McMichael, A. Biological invasions: Recommendations for US policy and management. Ecol. Appl. 2006, 16, 2035-2054.

3. Mooney, H.A. The ecosystem-services chain and biodiversity crisis. Philos. Trans. R. Soc. B 2010, 365, 31-39.

4. Turner, R.K.; Button, K.; Nijkamp, P. Ecosystems and Nature: Economics, Science and Policy; Edward Elgar Publishing: Cheltenham, UK, 1999.

5. United Nations Convention on Biological Diversity; UNEP: Montreal, Canada, 5 June 2005.

6. Nunes, A.L.D.; van den Bergh, C.J.M. Economic valuation of biodiversity: Sense or nonsense? Ecol. Econ. 2001, 39, 203-222.

7. Mozumder, P.; Berrens, R. Inorganic fertilizer use and biodiversity risk: An empirical investigation. Ecol. Econ. 2007, 62, 538-543.

8. Berrens, R. The safe minimum standard of conservation and endangered species: A review. Environ. Conserv. 2001, 28, 1-12.

9. Norton, B.G. Why Preserve Natural Variety? Princeton University Press: Princeton, NJ, USA, 1987.

10. Simpson, R.D. David Pearce and the economic valuation of biodiversity. Environ. Resour. Econ. 2007, 37, 91-109.

11. Mace, G.M.; Baillie, J.E. The 2010 biodiversity indicators: Challenge for science and policy. Conserv. Biol. 2007, 21, 1406-1413.

12. Beckerman, W. Economic growth and the environment: Whose growth? Whose environment? World Dev. 1992, 20, 481-496. 
13. Tierney, J. Use Energy, Get Rich and Save the Planet. New York Times: New York, NY, USA, 2009. Available online: http://www.nytimes.com/2009/04/21/science/earth/21tier.html?_r=2\&em (accessed on 21 April 2009).

14. Arrow, K.; Bolin, B.; Costanza, R.; Dasgupta, P.; Folke, C.; Holling, C.S.; Bengt-Owe, J.; Levin, S.; Maler, K.G.; Perrings, C.; Pimental, D. Economic growth, carrying capacity, and the environment. Ecol. Econ. 1995, 15, 91-95.

15. Cavlovic, T.; Baker, K.; Berrens, R.; Gawande, K. A Meta-analysis of environmental Kuznets curve studies. Agric. Resour. Econ. Rev. 2000, 29, 32-42.

16. Li, H.; Grijalva, T.; Berrens, R. Economic growth and environmental quality: A meta-analysis of environmental Kuznets curve studies. Econ. Bull. 2007, 17, 1-11.

17. Koirala, B.; Lui, H.; Berrens, R. Further investigation of environmental Kuznets curve studies using meta-analysis. Int. J. Ecol. Econ. Stat. 2011, 22, 13-32.

18. Reyers, B.; van Jaarsveld, A.S.; McGeoch, M.A.; James, A.N. National biodiversity risk assessment: A composite multivariate and index approach. Biodivers. Conserv. 1998, 7, 945-965.

19. Reyers, B.; James, A.N. An upgraded national biodiversity risk assessment index. Biodivers. Conserv. 1999, 8, 1555-1560.

20. Grossman, G.; Krueger, A.B. Environmental Impact of a North American Free Trade Agreement; National Bureau of Economic Research Working Paper 3914; NBER: Cambridge, MA, USA, 1991.

21. Shafik, N; Banyopadhyay, S. Economic Growth and Environmental Quality: Time Series and Cross-Sectional Evidence; Background Paper for the World Bank Development Report; The World Bank: Washington, DC, USA, 1992.

22. Kuznets, S. Economic growth and income inequality. Am. Econ. Rev. 1955, 45, 1-28.

23. Selden, T.M.; Song, D. Neoclassical growth, the J curve for abatement, and the inverted U curve for pollution. J. Environ. Econ. Manag. 1995, 29, 162-168.

24. Selden, T.M.; Song, D. Environmental quality and development: Is there a Kuznets curve for air pollution emissions. J. Environ. Econ. Manag. 1994, 27, 147-162.

25. Grossman, G.M.; Krueger, A.B. Economic growth and the environment. Q. J. Econ. 1995, 110, 353-377.

26. Deacon, R.T.; Norman, C.S. Does the environmental Kuznets curve describe how individual countries behave? Land Econ. 2006, 82, 291-315.

27. Merlevde, B.; Verbeke, T.; deClercq, M. The EKC for $\mathrm{SO}_{2}$ : Does firm size matter? Ecol. Econ. 2006, 59, 451-461.

28. Paudel, K.P.; Zapata, H.; Dwi, S. An empirical test of environmental Kuznets curve for water pollution. Environ. Resour. Econ. 2005, 31, 325-348.

29. Barbier, E. The economics of tropical deforestation and land use: An introduction to the special issue. Land Econ. 2001, 77, 155-171.

30. Culas, R.J. Deforestation and the environmental Kuznets curve: An institutional perspective. Ecol. Econ. 2007, 61, 429-437.

31. Rupasingha, A.; Goetz, S.J.; Debertin, D.L.; Angelos, P. The environmental Kuznets curve for US counties: A spatial economic analysis with extensions. Pap. Reg. Sci. 2004, 83, 407-424. 
32. Wang, P.; Berrens, R.; Bohara, A.; Gawande, K. An environmental Kuznets curve for risk-ranked US hazardous waste sites. Appl. Econ. Lett. 1998, 5, 761-764.

33. McConnell, K.E. Income and the demand for environmental quality. Environ. Dev. Econ. 1997, 2, 383-399.

34. Komen, R.; Gerking, S.; Folmer, H. Income and environmental R \& D: Empirical evidence from OECD countries. Environ. Dev. Econ. 1997, 2, 505-515.

35. Liddle, B. Free trade and the environment-development system. Ecol. Econ. 2001, 39, 21-36.

36. Gawande, K.; Berrens, R.; Bohara, A. A consumption based theory of the environmental Kuznets curve. Ecol. Econ. 2001, 37, 101-112.

37. Dietz, S.; Adger, W.N. Economic growth, biodiversity loss and conservation effort. J. Environ. Manag. 2003, 68, 23-35.

38. McPherson, M.A.; Nieswiadomy, M.L. Environmental Kuznets curve: Threatened species and spatial effects. Ecol. Econ. 2005, 55, 395-407.

39. Lantz, V.; Martinez-Espineira, R. Testing the environmental Kuznets curve hypothesis with bird population as habitat-specific environmental indicators: Evidence from Canada. Conserv. Biol. 2008, 22, 428-438.

40. Stork, N.E.; Samways, M.J. Inventorying and monitoring of biodiversity. In Global Biodiversity Assessment; Heywood, V.H., Ed.; Cambridge University Press: Cambridge, UK, 1995; pp. 453-544.

41. Mozumder, P.; Berrens, R.; Bohara, A.K. Is there an environmental Kuznets curve for the risk of biodiversity loss? J. Dev. Areas 2006, 39, 1-12.

42. Pandit, R.; Laband, D. Spatial autocorrelation in country-level models of species imperilment. Ecol. Econ. 2007, 60, 526-532.

43. Maddison, D. Environmental Kuznets curves: A spatial econometric approach. J. Environ. Econ. Manag. 2006, 51, 218-230.

44. Threatened and Endangered Species System; US Department of Interior, Fish and Wildlife Service: Washington, DC, USA, 2009. Available online: http://ecos.fws.gov/tess_public/pub/ stateListing. jsp? (accessed on 12 February 2009).

45. Major Uses of Land in the United States, 2002; US Department of Agriculture, Economic Research Service: Washington, DC, USA, 2007. Available online: http://www.ers.usda.gov/Data/ MajorLandUses/ (accessed on 19 August 2009).

46. Nowak, D.J.; Walton, J.T. Projected urban growth (2000-2050) and its estimated impact on the US forest resource. J. Forest. 2005, 383-389.

47. Population Estimates; US Census Bureau: Washington, DC, USA, 2009. Available online: http://factfinder. census.gov (accessed on 19 August 2009).

48. Bureau of Economic Analysis: Gross Domestic Product Data; US Department of Commerce: Washington, DC, USA, 2009. Available online: http://www.bea.gov/regional/gsp/ (accessed on 21 July 2009).

49. League of Conservation Voters. National Environmental Scorecard; League of Conservation Voters: Washington, DC, USA, 2010. Available online: http://www.lcv.org/scorecard/ (accessed on 25 October 2010). 
50. Stein, B.A. States of the Union: Ranking America's Biodiversity; Nature Serve and Nature Conservancy: Arlington, VA, USA, 2002.

51. US Department of Interior, Fish and Wildlife Service. Preliminary Certificate of Apportionment of \$240,541,414 of the Appropriation for Pittman-Robertson Wildlife Restoration to the States, the Commonwealth of Puerto Rico, Guam, the US Virgin Islands, American Samoa, and the Commonwealth of the Northern Mariana Islands for the fiscal year 2009; USDI: Washington, DC, USA, 2009.

52. Museum of Southwestern Biology, University of New Mexico. Multi-Institution, Multi-Collection Museum Database. Available online: http://arctos.database.museum/SpecimenSearch.cfm (accessed on 6 June 2011).

53. Jha, R.; Murthy, K.V.B. An inverse environmental Kuznets curve. J. Comp. Econ. 2003, 31, 352-368.

54. Paudel, K. P.; Schafer, M.J. The environmental Kuznets curve under a new framework: The role of social capital in water pollution. Environ. Resour. Econ. 2009, 42, 265-278.

55. Barbier, E. Natural Resource and Economic Development; Cambridge University Press: Cambridge, UK, 2005.

56. Benitez-Lopez, A; Alkemade, R.; Verweij, P.A. The impact of roads and other infrastructure on mammal and bird populations: A meta-analysis. Biol. Conserv. 2010, 143, 1307-1316.

57. Kerr, J.T.; Currie, D.J. Effects of human activity on global extinction risk. Conserv. Biol. 1995, 9 , 1528-1538.

58. Pandit, R.; Laband, D. Economic well-being, the distribution of income and species imperilment. Biodivers. Conserv. 2009, 18, 3219-3233.

59. Dinda, S. Environmental Kuznets curve hypothesis: A survey. Ecol. Econ. 2004, 49, 431-455.

60. Anselin, L. Spatial effects in econometric practice in environmental and resource economics. Am. J. Agric. Econ. 2001, 83, 705-710.

61. Anselin, L. Spatial Econometrics: Methods and Models; Kluwer Academic Publishers: Dordrecht, The Netherlands, 1988.

62. Bailey, T.C.; Gatrell, A.C. Interactive Spatial Data Analysis; Longman: Essex, UK, 1995.

63. Greene, W.H. Econometric Analysis, 2nd ed; Prentice Hall: Englewood Cliffs, NJ, USA, 1993.

64. Geary, R. The contiguity ratio and statistical mapping. Incorp. Stat. 1954, 5, 115-145.

65. Moran, P. The interpretation of statistical maps. J. R. Stat. Soc. 1948, 10, 243-251.

66. Breusch, T.; Pagan, A. The LM test and its application to model specification in econometrics. Rev. Econ. Stud. 1980, 47, 239-254.

(C) 2011 by the authors; licensee MDPI, Basel, Switzerland. This article is an open access article distributed under the terms and conditions of the Creative Commons Attribution license (http://creativecommons.org/licenses/by/3.0/). 